\title{
HYDROXY VITAMIN D STATUS IN TYPE 2 DIABETES MELLITUS
}

\author{
By
Mohammad Kamal Abdelbaky, Gamal Ali Badr, Mohammad Saed Alshorbagy, and Mohammad Qadry Mohammd Basiony \\ Internal Medicine Department, Al-Azhar Faculty of Medicine
}

\begin{abstract}
Background: The concurrent global epidemics of type-2 DM and vitamin D deficiency raise the question whether vitamin D deficiency should be included among the risk factors for DM. Evidence is accumulating on the possible role of vitamin $\mathrm{D}$ in the pathogenesis of type 2 diabetes.
\end{abstract}

Objectives: assessing 25-hydroxy vit D level in type-2 diabetes mellitus and correlating it with insulin resistance and other parameters.

Patients and Methods: This study had been carried out in the diabetes clinic of Internal Medicine Department and laboratory part was done in Clinical Pathology department, Faculty of Medicine, Al-Azhar University during the period from January 2015 to October 2017.

This study included a total number of 60 adult subjects (above 18 years old), the subjects were divided into 2 groups:

Group (A): Forty diabetic patients (type 2 diabetes mellitus) and Group (B): twenty non diabetic persons.

Results: 25(OH)D level was lower in diabetic patients than in non-diabetic group with a significant difference.

Conclusion: 25(OH)D was low in diabetic patients denoting that vitamin D status has a role in maintaining glucose homeostasis.

Key words: $25(\mathrm{OH}) \mathrm{D}$, Vitamin D deficiency, Diabetes mellitus.

\section{INTRODUCTION}

Vitamin D plays a key role in calcium and bone metabolism but emerging evidence suggests that its biological role extends beyond the skeletal system to influence a variety of systemic processes like inflammation, cell differentiation and immune regulation (D'Aurizio et al., 2015). This has led to extensive research exploring the association of vitamin D with a range of serious diseases like cancer, cardiovascular disease and type 2diabetes. Although the plausible underlying mechanisms are not well understood, low levels of vitamin D concentrations have been associated with impaired $\beta$ cell function (Alvarez and Ashraf, 2010) and insulin resistance, leading to alteration in glucose homeostasis, and, therefore type 2diabetes. Furthermore, vitamin D receptors have also been identified in vascular endothelium, smooth muscles and cardiomyocytes thereby implicating its potential role in microvascular and macrovascular disease, leading to increased risk of cardiovascular mortality in type 2 diabetes (Zoppini et al., 2015).

It has been widely reported that vitamin D is necessary for normal islet 
cell insulin secretion through direct and indirect action (Pittas et al., 2007). The direct effect is suggested by the binding of $1,25(\mathrm{OH}) 2 \mathrm{D} 3$ to VDR on $\beta$ cells, by identification of vitamin $\mathrm{D}$ response element (VDRE) in the human insulin gene promoter (Maestro et al., 2003) and by the transcriptional activation of the human insulin gene caused by 1,25(OH)2D3. Several signalling pathways have been reported to play critical roles in insulin secretion and $\beta$ cell growth and survival. A key regulator is 'Akt' located downstream in the insulin pathway which, when activated, induces phosphorylation thereby reducing the toxic effects of glucose and fatty acids on $\beta$ cells. In addition, activation of $\mathrm{Akt} / \mathrm{JNK}$ pathways by vitamin $\mathrm{D}$ can also regulate the activity of angiotensin (an active component of the renin-angiotensin system) mediated islet endothelial cell apoptosis and improve islet cell function and survival (Leung, 2015). Many studies also found that vitamin D supplementation could improve glycemic control in diabetic patients (Chunhua et al., 2017).

Vit. D deficiency may also impair insulin secretion through VDD-associated hyperparathyroidism which may actually cause a paradoxical increase in intracellular calcium level impairing the calcium signal needed for glucose-induced insulin secretion.

The aim of the present work was to assess the level of $25(\mathrm{OH}) \mathrm{D}$ in diabetes mellitus, and its correlation with insulin resistance and other parameters.

\section{PATIENTS AND METHODS}

This study had been carried out in the diabetes clinic of Internal Medicine
Department, and the Laboratory part in Clinical Pathology Department, Faculty of Medicine, Al-Azhar University during the period from January 2015 to October 2017. This study included a total number of 60 adult subjects matched with age and sex, and agreed to participate in this study. The subjects have been divided into 2 groups:

Group (A): Forty diabetic patients (type 2 diabetes mellitus).

Group (B): included 20 non diabetic persons matched with age and sex.

All subjects were subjected to:

1. Full history taking (duration of diabetes mellitus, mode of treatment and any diabetic complications).

2. General examination including: weight, height, waist circumference, Arterial blood pressure (ABP) and Body mass index (BMI) and laboratory investigations including lipid profile, kidney function test, liver function test, Complete blood count, Serum calcium (total, ionized), Serum phosphorus, fasting insulin, $25(\mathrm{OH}) \mathrm{D}$, fasting blood sugar, post prandial blood sugar, HbA1c, urine analysis and (HOMA-IR) test.

The study used widely accepted cut-off values for $25(\mathrm{OH}) \mathrm{D}$ to create four vitamin D categories: severe deficiency, <10 $\mathrm{ng} / \mathrm{ml}(25 \mathrm{nmol} / \mathrm{l})$; moderate deficiency, 10-19.9 $\mathrm{ng} / \mathrm{ml} \quad(25-49.9 \quad \mathrm{nmol} / \mathrm{l})$; insufficiency, $20-29.9 \mathrm{ng} / \mathrm{ml} \quad$ (50-74.9 $\mathrm{nmol} / \mathrm{l}) ; \quad$ sufficiency, $\geq 30 \mathrm{ng} / \mathrm{ml} \quad(75$ nmol/l) (Bischoff-Ferrari et al., 2006). 


\section{Statistical Analysis:}

Data were analyzed using Statistical Program for Social Science (SPSS) version 23. Independent-samples t-test of significance was used when comparing between two means. Mann Whitney U test was used when comparing two means of not normally distributed data. Chi-square
(X2) test of significance was used in order to compare proportions between two qualitative parameters. Spearman's correlation coefficient (r) test was used for correlating data. Spearman's correlation coefficient (r) test was used for correlating data. $\mathrm{P}$ value $\leq 0.05$ was considered significant.

\section{RESULTS}

Our results showed that $25(\mathrm{OH}) \mathrm{D}$ was lower in patients with type 2 diabetes mellitus and there was a significant inverse relation between $25(\mathrm{OH})$ vitamin $\mathrm{D}$ and type 2 diabetes mellitus (Table 1).
There was a significant difference between the two studied groups as regard fasting and post prandial blood and a significant difference between the two studied groups as regard HbA1c (Table 1).

Table (1): Comparison between the studied groups regarding Fasting blood sugar (F.B.S), post prandial blood sugar (P.P.B.S) and glycated hemoglobin (HbA1c)

\begin{tabular}{|c|c|c|c|}
\hline $\begin{array}{ll}\text { Parameters } & \text { Groups } \\
\end{array}$ & $\begin{array}{c}\text { Controls } \\
\text { (non-diabetics) }\end{array}$ & $\begin{array}{c}\text { Cases } \\
\text { (diabetics) }\end{array}$ & \multirow[t]{2}{*}{ p-value } \\
\hline Number $(\%)$ & $20(33.3 \%)$ & $40(66.7 \%)$ & \\
\hline \multicolumn{4}{|l|}{ F.B.S (mg/dL) } \\
\hline Mean \pm SD & $95.5 \pm 5.1$ & $196.5 \pm 48.5$ & \multirow[t]{2}{*}{$<0.001$} \\
\hline Median (Range) & $98(87-101)$ & $\begin{array}{r}192.5(110- \\
299)\end{array}$ & \\
\hline \multicolumn{4}{|l|}{ P.P.B.S (mg/dL) } \\
\hline Mean \pm SD & $113.8 \pm 5.4$ & $269.2 \pm 50.1$ & \multirow[t]{2}{*}{$<0.001$} \\
\hline Median (Range) & $\begin{array}{r}112.5(103- \\
123)\end{array}$ & $271(189-380)$ & \\
\hline \multicolumn{4}{|l|}{ HbA1c (\%) } \\
\hline Mean \pm SD & $4.56 \pm 0.36$ & $7.7 \pm 0.83$ & \multirow[t]{2}{*}{$<0.001$} \\
\hline Median (Range) & $4.7(4-5)$ & $7.6(5.5-9.4)$ & \\
\hline
\end{tabular}

- Mann Whitney U test.

There was no significant difference between the two studied groups as regards total calcium or ionized calcium. There was a significant difference between the two studied groups as regards serum phosphorus, and between the two studied groups as regards $25(\mathrm{OH}) \mathrm{D}$ (Mean $\pm \mathrm{SD}$ in diabetic patients $41.4 \pm 9.9$ and in nondiabetics $31.0 \pm 7.8$ ) (Table 2). 
Table (2): Comparison between the studied groups regarding serum calcium, phosphorus and 25(OH)D levels

\begin{tabular}{|c|c|c|c|}
\hline $\begin{array}{ll}\text { Parameters } & \text { Groups } \\
\end{array}$ & $\begin{array}{c}\text { Controls } \\
\text { (non-diabetics) }\end{array}$ & $\begin{array}{c}\text { Cases } \\
\text { (diabetics) }\end{array}$ & \multirow[t]{2}{*}{ p-value } \\
\hline Numbers $(\%)$ & $20(33.3 \%)$ & $40(66.7 \%)$ & \\
\hline \multicolumn{4}{|l|}{$\begin{array}{l}\text { Total calcium } \\
(\mathrm{mg} / \mathrm{dL})\end{array}$} \\
\hline Mean \pm SD & $9.7 \pm 0.49$ & $9.7 \pm 0.53$ & \multirow[t]{2}{*}{$>0.05$} \\
\hline Median (Range) & $9.6(8.8-10.5)$ & $9.9(8.8-10.5)$ & \\
\hline \multicolumn{4}{|l|}{$\begin{array}{l}\text { Ionized calcium } \\
(\mathrm{mg} / \mathrm{dL})\end{array}$} \\
\hline Mean \pm SD & $5.0 \pm 0.18$ & $5.0 \pm 0.19$ & \multirow[t]{2}{*}{$>0.05$} \\
\hline Median (Range) & $5.0(4.8-5.4)$ & $5.0(4.6-5.3)$ & \\
\hline \multicolumn{4}{|l|}{ Phosphorus (mg/dL) } \\
\hline Mean \pm SD & $3.9 \pm 0.35$ & $3.6 \pm 0.51$ & \multirow[t]{2}{*}{0.002} \\
\hline Median (Range) & $3.9(3-4.3)$ & $3.6(2.8-4.8)$ & \\
\hline \multicolumn{4}{|l|}{25 (OH) Vit.D (ng/ml) } \\
\hline Mean \pm SD & $41.4 \pm 9.9$ & $31.0 \pm 7.8$ & \multirow[t]{2}{*}{$<0.001$} \\
\hline Median (Range) & $39(29-70)$ & $31.5(7-41)$ & \\
\hline
\end{tabular}

- Mann Whitney U test.

There was no significant difference between the two studied groups as regards fasting insulin, and between the two studied groups as regards HOMA IR (Table 3).

Table (3): Comparison between the studied groups regarding fasting insulin level and HOMA IR test

\begin{tabular}{|c|c|c|c|}
\hline $\begin{array}{ll}\text { Parameters } & \text { Groups } \\
\end{array}$ & $\begin{array}{c}\text { Controls } \\
\text { (non-diabetics) }\end{array}$ & $\begin{array}{c}\text { Cases } \\
\text { (diabetics) }\end{array}$ & \multirow[t]{2}{*}{ p-value } \\
\hline Numbers (\%) & $20(33.3 \%)$ & $40(66.7 \%)$ & \\
\hline \multicolumn{4}{|l|}{$\begin{array}{ll}\text { Fasting } & \text { insulin } \\
(\mathrm{mIU} / \mathrm{L}) & \\
\end{array}$} \\
\hline Mean \pm SD & $5.66 \pm 1.86$ & $7.86 \pm 6.23$ & \multirow[t]{2}{*}{$>0.05$} \\
\hline Median (Range) & $5.3(3.2-9.2)$ & $6.75(1.0-19.1)$ & \\
\hline \multicolumn{4}{|l|}{ HOMA IR } \\
\hline Mean \pm SD & $6.06 \pm 20.94$ & $3.73 \pm 3.18$ & \multirow[t]{2}{*}{$>0.05$} \\
\hline Median (Range) & $1.36(0.7-95)$ & $\begin{array}{c}2.84(0.33- \\
13.3)\end{array}$ & \\
\hline
\end{tabular}

- Mann Whitney U test.

There was no significant difference between HOMA-IR and 25(OH)D, and between duration of diabetes and 25(OH)D. There was a significant negative correlation between $\mathrm{HbA} 1 \mathrm{c}$ and $25(\mathrm{OH}) \mathrm{D}$, and between BMI and 25(OH)D(Table 4). 
Table (4): Spearman's correlation between 25(OH) D and other parameters

\begin{tabular}{|l|l|c|}
\hline \multicolumn{2}{|c|}{} & $\mathbf{2 5}(\mathbf{O H}) \mathbf{D}(\mathbf{n g} / \mathbf{m l})$ \\
\hline HOMA IR & P-value & $>0.05$ \\
\hline HbA1c $(\%)$ & P-value & -.533 \\
\hline BMI & P-value & -.387 \\
\hline Duration of diabetes & P-value & $>0.05$ \\
\hline
\end{tabular}

\section{DISCUSSION}

Some studies suggested that vit D could have a direct (via its role on the activation of pancreatic beta-cell and sensitive organs) or indirect There is a controversy about the extra skeletal effects of vitamin D. Epidemiological data together with the demonstration of the presence of vitamin D receptor in multiple organs suggest a link between vitamin D and multiple diseases, including type 2 diabetes mellitus (DM). Vitamin D deficiency is common in all populations and age groups (Calvo-Romero and Ramiro-Lozano, 2015).

In a population-based study in a sunny country like Spain, $34.7 \%$ of a sample of 1226 individuals had vitamin D deficiency, defined as a level of serum 25hydroxy vitamin D $(25(\mathrm{OH}) \mathrm{D})$ lower than 20 ng/mL (Gonz?lez-Molero et al., 2013).

Our results showed that $25(\mathrm{OH}) \mathrm{D}$ was lower in patients with type 2 diabetes mellitus. These findings went with (Bayani et al., 2014) who found that vitamin D concentration was significantly lower in diabetic patients than the healthy individuals. Our results was supported by (Mauss et al., 2015) that was a crosssectional study.

(Gagnon et al., 2011) found that the mean serum concentration of vit $\mathrm{D}$ in diabetic patients was lower than the nondiabetic individuals.

(Scragg et al., 2005) found an inverse association between vitamin D status and diabetes, possibly involving insulin resistance, in non-Hispanic whites and Mexican Americans.

On the other hand (Sheth et al., 2015) did not support our results as they found no effect of serum $25(\mathrm{OH}) \mathrm{D}$ deficiency on HbA1c or HOMA-IR in T2DM cases. The discrepant results obtained in the reported studies could be attributed to the inclusion of patients with different degrees of sun exposure or different types of food intake and different duration of diabetes.

(Robinson et al., 2011) did not support our results as they found that lower serum $25(\mathrm{OH}) \mathrm{D}$ levels were not associated with increased risk of developing type 2 diabetes in this racially and ethnically diverse population of postmenopausal women.

We also found no significant correlation between serum $25(\mathrm{OH}) \mathrm{D}$ levels with HOMA IR and fasting insulin. That agreed with (Sheth et al., 2015) who found no effect of serum 25(OH)D deficiency on HOMA-IR in T2DM cases. (Hjelmes? th et al., 2009) also found that $25(\mathrm{OH}) \mathrm{D}$ did not differ significantly in patients with metabolic syndrome and 
patients without metabolic syndrome. Our study disagreed with study of (Al-Daghri et al., 2013) and (Calvo-Romero and Ramiro-Lozano., 2015), who found an inverse correlation between serum 25(OH)D levels and insulin and HOMAIR. The discrepant results obtained in the reported studies could be attributed to the inclusion of patients with different duration of diabetes and different degrees of insulin resistance and beta cell dysfunction.

\section{CONCLUSION}

$25(\mathrm{OH}) \mathrm{D}$ level is low in diabetic patients and that support the hypothesis that Vitamin D possibly plays a role in maintaining glucose homeostasis, and $25(\mathrm{OH}) \mathrm{D}$ level has a negative correlation with type 2 diabetes mellitus.

\section{REFERENCES}

1. Al-Daghri, N. M., Al-Attas, O. S., Alokail, M. S., Alkharfy, K. M., Al-Othman, A., Draz, H. M. and Clerici, M. (2013): Hypovitaminosis D associations with adverse metabolic parameters are accentuated in patients with Type 2 diabetes mellitus: a body mass index-independent role of adiponectin? Journal of Endocrinological Investigation, 36(1): 1-6.

2. Alvarez, J. A. and Ashraf, A. (2010): Role of vitamin $\mathrm{D}$ in insulin secretion and insulin sensitivity for glucose homeostasis. International Journal of Endocrinology, 10(1):1-9.

3. Bayani, M. A., Akbari, R., Banasaz, B. and Saeedi, F. (2014): Status of Vitamin-D in diabetic patients. Caspian Journal of Internal Medicine, 5(1): 40.

4. Bischoff-Ferrari, H. A., Giovannucci, E., Willett, W. C., Dietrich, T., and DawsonHughes, B. (2006): Estimation of optimal serum concentrations of 25-hydroxyvitamin D for multiple health outcomes. The American Journal of Clinical Nutrition, 84(1): 18-28.
5. Calvo-Romero, J. M. and Ramiro-Lozano, J. M. (2015): Vitamin D levels in patients with type 2 diabetes mellitus. Journal of Investigative Medicine, 63(8): 921-923.

6. D'Aurizio, F., Villalta, D., Metus, P., Doretto, P. and Tozzoli, R. (2015): Is vitamin D a player or not in the pathophysiology of autoimmune thyroid diseases?. Autoimmunity Reviews, 14(5):363:369.

7. Gagnon, C., Lu, Z. X., Magliano, D. J., Dunstan, D. W., Shaw, J. E., Zimmet, P. Z. and Daly, R. M. (2011): Serum 25-hydroxy vitamin $\mathrm{D}$, calcium intake, and risk of type 2 diabetes after 5 years: results from a national, population-based prospective study (the Australian Diabetes, Obesity and Lifestyle study). Diabetes Care, 34(5):1133:1138.

8. Gonzalez-Molero, I., Rojo-Martinez, G., Morcillo, S., Gutierrez, C., Rubio, E., PerezValero, V. and Olveira, G. (2013): Hypovitaminosis D and incidence of obesity: a prospective study. European Journal of Clinical Nutrition, 67(6): 680.

9. Hjelmes? th, J., Hofs?, D., Aasheim, E. T., Jenssen, T., Moan, J., Hager, H. and Bollerslev, J. (2009): Parathyroid hormone, but not vitamin $\mathrm{D}$, is associated with the metabolic syndrome in morbidly obese women and men: a cross-sectional study. Cardiovascular diabetology, 8(1):7.

10. Leung, Po Sing (2007): The physiology of a local renin-angiotensin system in the pancreas. The Journal of Physiology 580.1: 31-37.

11. Maestro, B., D?vila, N., Carranza, M. C. and Calle, C. (2003): Identification of a Vitamin D response element in the human insulin receptor gene promoter. The Journal of Steroid Biochemistry and Molecular Biology, 84(2-3):223-230.

12. Mauss, D., Jarczok, M. N., Hoffmann, K., Thomas, G. N. and Fischer, J. E. (2015): Association of vitamin D levels with type 2 diabetes in older working adults. International Journal of Medical Sciences, 12(5): 362.

13. Pittas, A. G., Lau, J., Hu, F. B. and DawsonHughes, B. (2007): The role of vitamin D and calcium in type 2 diabetes. A systematic review and meta-analysis. The Journal of Clinical 
Endocrinology and Metabolism, 92(6): 20172029.

14. Robinson, J. G., Manson, J. E., Larson, J., Liu, S., Song, Y., Howard, B. V. and Johnson, K. C. (2011): Lack of association between $25(\mathrm{OH}) \mathrm{D}$ levels and incident type 2 diabetes in older women. Diabetes Care, 34(3):628-634.

15. Scragg, R., Sowers, M. and Bell, C. (2004): Serum 25-hydroxyvitamin D, diabetes, and ethnicity in the Third National Health and Nutrition Examination Survey. Diabetes Care, 27(12):2813-2818.

16. Sheth, J. J., Shah, A., Sheth, F. J., Trivedi, S., Lele, M., Shah, N and Vaidya, R. (2015): Does vitamin D play a significant role in type 2 diabetes?.BMC Endocrine Disorders, 15(1): 5.
17. Song, Y. and Wang, B. (2013): Survey on reliability of power electronic systems. IEEE Transactions on Power Electronics, 28(1): 591604.

18. Wu, Chunhua, Shanhu Qiu, Xiangyun Zhu and Ling Li (2017): Vitamin D supplementation and glycemic control in type 2 diabetes patients: A systematic review and meta-analysis. Metabolism, 73: 67-76.

19. Zoppini, G., Galletti, A., Targher, G., Brangani, C., Pichiri, I., Trombetta, M. and Bonora, E. (2015): Lower levels of 25hydroxyvitamin D3 are associated with a higher prevalence of microvascular complications in patients with type 2 diabetes. BMJ Open Diabetes Research and Care, 3(1): e000058. 


\section{مستوى 0Y ـ هيدروكسي فيتامين د في مرض البو ال السكرى من النوع الثناني}

محمد كمال عبد الباقي - جمال على بلر - محمد سعيد الثوربجي - محمد قدرى محمد بسيونى قسم الأمراض الباطنية ـ كلية الطب - جامعة الأزهر

خلفية البحث : نسبة فيتامين دال فى الدم لها علاقة قريبة بمـا قبل السكرى و الذي يؤدى إلى البو ال

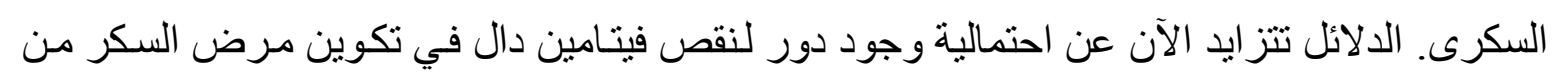

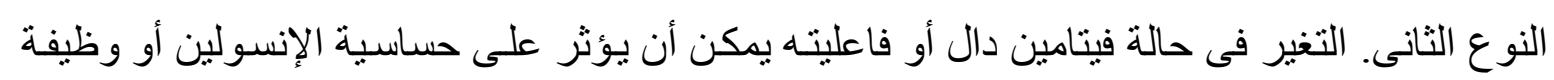
خلايا بيتا أو الإثثين.

الهلف من البحث: تقييم مستوى هب ـ هيدروكسي فيتامين د في مرض البو ال السكرى من النوع الثناني

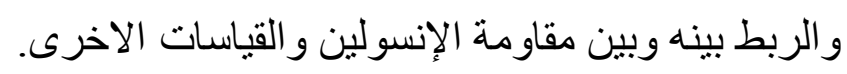

المرضى وطرق البحث: أجريت هذه الدراسة بعيادة السكر بقسم الباطنة العامة و الجزء المعملي بقسم

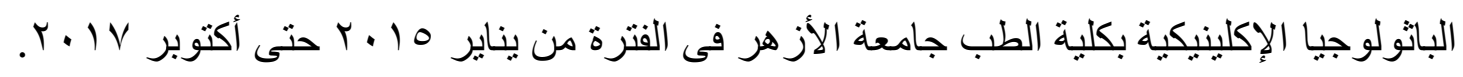

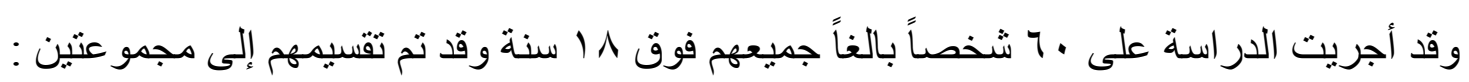
مجمو عة (أ) : وتتكون من · ـ مريضاً بالبو ال السكرى من النوع الثاني. مجموعة (ب) : وتتكون من · ب فرداً غير مصابين بالبو ال السكرى.

النتائج: مستوى ه ـ هيدروكسي فيتامين د كان اقل فى مرضي السكر عن غير مرضي السكر وكان الفرق ذو دلالة إحصائية.

الاستنتاج: فيتامين دال أقل فى مرضي السكر من النوع الثاني مما يشير إلى أن فيتامين د لـه دور فى تنظيم مستوى السكر بالدم. 